\title{
住環境の健康リスク要因とそのマネジメントに関する国内外の動向
}

\author{
東一賢一 \\ 近畿大学医学部環境医学・行動科学教室
}

\section{Health Risk Factors for Housing Environment and Risk Management}

\author{
Kenichi AZUMA \\ Department of Environmental Medicine and Behavioral Science, Kindai University Faculty of Medicine
}

\begin{abstract}
After the 1990s, many effective measures were taken to improve indoor air pollution in Japan. However, as a result of major changes in building materials, consumer products, and lifestyle, and new scientific findings on health effects associated with indoor environmental pollution, new issues have been indicated, such as chemical pollutants in indoor dusts or indoor pollutants caused by new chemicals that were substituted from chemicals that Indoor Air Quality Guideline was set. On the other hand, scientific evidence for the links between housing environment and health has accumulated substantially in recent decades. Therefore, the World Health Organization (WHO) is developing Housing and Health Guidelines to provide policymakers with recommendations on healthy housing conditions such as thermal comfort, indoor air pollution, crowding, and home injuries. In this paper, the basic principles of healthy housing, the current status of Japanese dwellings, and the recent approaches of WHO are summarized.
\end{abstract}

Key words: guideline（ガイドライン）, health risk（健康リスク）, burden of disease（疾病負荷）, housing environment (住環境), inadequate housing（不適切な住宅）

はじめに

日本では 1990 年代に入り，住環境に起因する健康影 響の問題として，いわゆるシックハウス問題が発生し， その中でも特に化学物質による室内空気污染の問題が明 らかにされてきた。そのため 1997 年から 2002 年にかけ て，13 の化学物質に対して厚生労働省より室内濃度指 針値が策定され，この指針值に基づき，建築基準法，住 宅の品質確保の促進等に関する法律，学校保健安全法， 建築物に打ける衛生的環境の確保に関する法律（建築物 衛生法）が改正された。これらは良質な室内の空気質を 確保するための取り組みである。一方，住環境の健康り

受付 2017 年 8 月 1 日, 受理 2017 年 10 月 18 日

Reprint requests to: Kenichi AZUMA

Department of Environmental Medicine and Behavioral Science, Kindai University Faculty of Medicine, 377-2 Ohnohigashi, Osakasayama, Osaka 589-8511, Japan

TEL: +81(72)366-0221 (ext3274), FAX: +81(72)368-1192

E-mail: kenazuma@med.kindai.ac.jp
スク要因には，空気質以外にも多種類の要因がある。そ こで本報では，住環境に求められる基礎的要件と世界保 健機関の動向を概説したい。

\section{公衆衛生と住居衛生学}

長与専斎が明治 4 年（1871 年）に欧州を視察したこ とをきっかけに, 日本では公衆衛生の概念が導入された。 長与専斎は，伝染病の予防，貧民の扶助，上下水道の整 備や家屋建築に至るまで，公衆衛生制度には，人間生活 の利害に関わる要因が細大となく網羅されていることに 着目した。当時より, 公衆衛生は, 身体よりも, 空気, 水, 住居などの身体をとりまく環境が対象であることがうた われていた。その後, 森林太郎 (森鴎外) による「日本 家屋説自抄」，小池正直による「家屋衛生」など，日本 の医学研究者は, 住宅の衛生問題に対して明治前半期か ら積極的に研究や提案を行ってきた (1)。

第二次世界大戦後, 都市部を中心に大規模な建築物が 多数建設され，不適切な建築物の維持管理に起因する健 
康影響の事例がいくつも報告されたことをきっかけに， 1970 年に建築物衛生法が制定された。この法律の適用 範囲は, 法令で定められた特定建築物 (延床面積 $3,000 \mathrm{~m}^{2}$ の事務所や店舗など）のみであり，個人が自主的に管理 できない建築物を対象にしたことがその理由の 1 つで あった。一般の住宅は, 個人が管理可能との考えに基づ き, この法律の対象外となった。医学に打ける住居衛生 学は, この頃までは機能していたようであるが, その後, この分野の研究者は皃とんどいなくなった。1970年代 に入り, 室内に設置された食器戸棚の悪臭が合板の接着 剂由来のホルムアルデヒドであるとの指摘がなされ，日 用品に含まれる化学物質による健康影響が着目されるよ らになった。そのため 1980 年代頃には, 国立研究機関 や地方衛生研究所が中心となり, 室内空気中の化学物質 等の実態調査が行われてきた (1)。また, 化学産業や建 築技術の発達, 省エネや耐震などの要求に伴い, 住宅に は多種多様の建材や建築工法が使用されるようになり, 住宅の高気密化と相まって, いわゆるシックハウス症候 群など, 住居衛生に関わる問題が 1990 年代に再び大き くなり今日に至っている。

\section{住環境に求められる基礎的要件}

18 世紀後半の産業革命後, 都市部には多くの労働者 が流入し，衛生的環境が著しく悪化した。イギリスでは 衛生状態の改善を目的とした公衆衛生法が 1848 年に制 定され，現在では住居法に受け継がれている。衛生は， 19 世紀の欧州で, 産業革命後の都市化による住環境の 悪化等による伝染病の曼延などに対応するなかで生まれ た概念である $(1)$ 。

その後, アメリカ公衆衛生協会 (APHA) の住宅衛生 委員会は, 1938 年に健康住宅の基本原則を定めた (2)。
この原則では, 生理学的要求, 心理学的要求, 感染予防, 事故防止の4要素に関する 30 項目の基本原則を定め, 肉 体的, 精神的, 社会的健康のための必要最低限度として いる（図 1）。この原則では，産業の発達に伴ら都市生活 環境の悪化に対応し，衛生的な環境を確保するための基 礎的要件として, 防湿を含む温熱環境, 空気質, 採光や 照明, 騷音などの生理学的要求, 個人のプライバシー保 護や家族の団らん，地域社会とのつながりの確保や景観 への配慮などに関する心理的要求, 住居の過密防止や飲 食物の衛生確保などによる感染予防, 火災や転倒や感電 などによる事故防止など, 幅広い要素が網羅されている。

APHA が定めた 30 の基本原則のらち，その多くが日 本の住宅に対しても取り組まれ，法令や指針などに反映 されてきた。水道施設の普及と水道法による水質管理で 水系消化器感染症は減少し, 住生活基本法によって居住 面積水準は大幅に向上した。近年は, 高齢者居住住宅の 設計指針により，高齢者や障害者に配慮したユニバーサ ルデザインの普及促進が進められている(3)。

その一方で, 生理学的要求に関する項目に打いては, いくつかの課題があると考光られる。近年, 地球温暖化 や都市部のヒートアイランド現象などにより, 熱中症が 増加している。熱中症の死亡数が多いのは，年齢では 65 歳以上, 発生場所では住居が多い(3)。日本救急医学 会の全国調査によると，住宅でのエアコンの未使用者と 非設置者において，熱中症の重症度が高かったと報告さ れている (4)。熱中症のリスク要因には, 気温以外に運 動や労働, 高齢, 独居, 日常生活動作の低下, 精神疾患 や心疾患などの基礎疾患などが関与するが，室温の確認 と適切な調節は熱中症予防に重要な役割を果たす。

寒冷な居住環境では，心拍数や血圧の変化により，循 環器疾患のリスクが増大する。また，寒冷な空気は，気 道感染や，喘息等の閉塞性気道疾患のリスクを上昇させ

\section{生理学的要求 \\ 1. 寒さに対する適切な温熱環境 \\ 2. 暑さに対する適切な温熱環境 \\ 3. 良質な空気質 \\ 4. 適度な日光照明の導入 \\ 5. 直射日光の導入 \\ 6. 適度な人工照明の設置 \\ 7. 騒音防止 \\ 8. 運動や子どもの遊戯用の適切な空間}

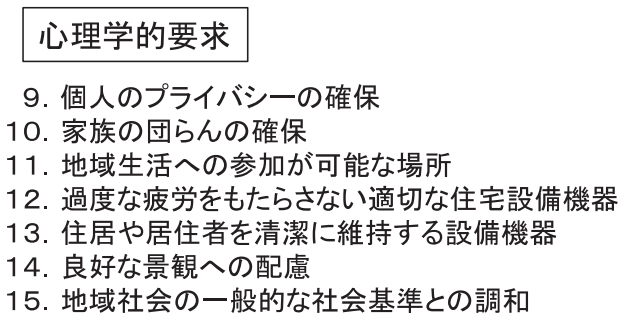

\author{
感染予防 \\ 16. 安全で衛生な給水 \\ 17. 住居内での污染に対する給水システムの保護 \\ 18. 伝染病の感染予防に配慮した屋内便所 \\ 19. 住居内における下水污染に対する保護 \\ 20. 住居近辺の不衛生状態の回避 \\ 21. 伝染病を媒介する害虫の駆除 \\ 22. ミルクと食品の貯蔵設備 \\ 23. 感染予防のため寝室の空間を十分に確保
}

図 1 アメリカ公衆衛生協会による健康住宅の基本原則 [文献（2）をもとに作成］ 
る。近年, 夜間の光曝露によるヒトの生体リズムへの影 響が報告されている。住居の寒冷曝露による高齢者の健 康影響や就寝時の光曝露による健康影響については, そ れぞれ本号のミ二特集に打故る奈良県立医科大学の佐伯 圭吾先生と大林賢史先生の総説を参照されたい。

湿度を表す指標として相対湿度がよく利用される。低 湿度ではインフルエンザウイルスの活性が増加すると報 告されてきた $(5,6)$ 。近年は, 動物への曝露実験による感 染力の研究が報告されて和り, 低湿度ではウイルスを含 む飛沫核の安定性が高いことから感染力が高いと考光ら れている $(7,8)$ 。また, 疫学研究では, インフルエンザ発 症前の温度と絶対湿度の平均值, 温度と絶対湿度の低下 率を比べた場合, 温度よりも絶対湿度, 平均值よりも低 下率がインフルエンザの発症リスクに強く関係している ことが示唆されている $(9)$ 。一般的な風邪の症状を引き 起こすライノウイルスについても，インフルエンザウイ ルス活どではないが，温度と絶対湿度の低下とウイルス 感染リスクとの関係が疫学研究で示唆されている (10)。

過剩な湿気は，カビやダニなどの増殖を促し，喘息の 増悪や上気道症状, 呼吸器感染との関係が十分あると判 断されている。そのため世界保健機関 (WHO) 欧州事 務局は，湿気とカビに関する室内空気質ガイドラインを 2009 年に公表した (11)。但し, 湿気やカビの量と健康 影響との関係関する定量的な知見が不足しており, 適 切な温度制御や換気等の維持管理に関する指針が提供さ れている。

騒音によるヒトの影響について，これまでは航空機騒 音に対する難聴や不快感（アノイアンス）の評価を中心 に研究が進められ, 騒音敒関する環境基準もアノイアン スを指標として策定されてきた。しかし，近年では欧米 を中心に，道路交通騒音が虚血性心疾患や高血圧症など の有症率に影響を及ぼすことを示唆した知見が増加して いる。そこで WHO 欧州事務局は, 夜間の騒音レベルの 推奨ガイドライン值を公表している(12)。このガイド ラインでは, $30 \mathrm{~dB}$ 以上の屋外夜間騒音で睡眠妨害が増 加し, $55 \mathrm{~dB}$ を超えると循環器系への影響が影著になる とされ，道路交通騒音と心血管系疾患の関係に着目して いる。

化学物質による室内空気污染に対しては，前述のよう に, 日本では多くの取り組及が行わ玌てきた。最近では, 北海道大学の岸玲子先生を研究代表者とする厚生労働科 学研究班によって,「科学的根拠に基づくシックハウス 症候群に関する相談マニュアル(改訂新版)」が作成され, 厚生労働省シックハウス対策のホームページにこのマ ニュアルが揭載された。一方, 室内の八ウスダストといっ た空気質以外の住環境污染がアレルギー疾患やシック八 ウス症候群様症状と関係していることが示唆されて招 り，今後の課題といえる。こ扎らについては，本号のミ 二特集に㨟ける北海道大学の岸玲子先生と荒木敦子先生 の総説を参照されたい。

な氺，厚生労働省では，2012 年以降，室内濃度指針
値の見直しを進めている（13）。1997 年から 2002 年にか けて 13 の化学物質に対して室内濃度指針値が策定され た後，指針值が策定されている化学物質の代替物質とし て新たな化学物質が使用されているとの指摘や，準揮発 性有機化合物による健康影響が疫学研究や動物実験等で 報告されたことなぼから、シックハウス（室内空気污染） 問題に関する検討会を再開し，室内濃度指針值の新設や 改訂を含めた室内空気污染対策の検討を進めている。代 替物質に上る健康影響を防止するには，継続的な室内濃 度の調査と健康りスク評価が必要である。そのため, 全 国規模での室内空気污染状況の実態を調査し, 高濃度か つ高頻度で検出される化学物質に対する健康りスクの初 期評価を実施し，検討対象となる化学物質の優先付忖を 行ら作業を進めている。

高濃度から高頻度検出された化学物質として, これま で2-エチルヘキサノール，テキサノール，2,2,4-トリメ チル-1,3-ペンタンジオールジイソブチレート (TXIB), 酶酸エステル類，グリコールエーテル類などがあげられ ている。2017年度に入り，2-エチルヘキサノール，テ キサノール，TXIB の指針值案が公表され，キシレン， エチルベンゼン, フタル酸ジ-n-ブチル, フタル酸ジ-2エチルヘキシルの指針值については，有害性に関する最 新の知見に基づいた改定案が公表されている（14）。

\section{世界保健機関による住宅と健康ガイドライン}

WHO 欧州事務局には住宅と健康 (housing and heath) の部門があり,これまで調査研究やガイドラインの開発 に取り組んできた。2011 年には不適切 (inadequate) な住 宅の状態による居住者の健康リスクに関する調查報告が なされ，表 1 亿示す疾病負荷（burden of disease）要因が あげられている(15)。この報告では，室内空気污染のみ ならず, 寒冷曝露, 騷音, 過密性 (低居住面積水準), 住 居内負傷などが高いリスク要因であることを報告してい る。また WHO 本部は, 住宅と健康及び気候変動関す る国際ワークショップを2010年に開催し, 住居内負傷, 室内空気污染，過密性などを課題として取り上げ，一次 予防のためのガイドラインが必要と報告している(16)。

WHO 本部では，近年，環境に扔ける不均衡または不 平等 (environmental inequality) の問題に取り組んでいる

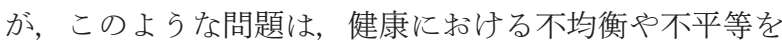
もたらす。特にWHO は，住宅に和忊る不衛生や不安全 な状態を重要な問題と位置づけている。そこでWHOは, 居住者の健康に影響を及活す住宅の状態について，これ までの科学的エビデンスに基づいた住宅と健康のガイド ライン (Housing and Health Guidelines) の開発を進めて いる(17)。これまでのところ, 住居内の過密性（感染 症対応），住居内のアクセスのしやすさ（バリアフリー なぞの高齢者や障害者対応)，負傷要因に対する安全性 (ベランダの手すり，階段の落差なぞ住居内負傷への対 応），過剩な暑さや寒さ，適切なエネルギー対策，居住 
表 1 不適切な住宅の状態による環境の疾病負荷［文献（15）をもとに作成］

\begin{tabular}{|c|c|c|}
\hline 曝露因子 & 健康影響，障害等 & リスク \\
\hline カビ & 0-14 歳の子ぞもの喘息死と年齢調整生存年数（DALYs） & 相対危険度 2.4 \\
\hline 湿気 & 0-14 歳の子ぞもの喘息死と年齢調整生存年数（DALYs） & 相対危険度 2.2 \\
\hline 空の柵の欠如 & 0-14 歳の子ぞもの傷害死と年齢調整生存年数（DALYs） & 相対危険度 2.0 \\
\hline 煙探知器の欠如 & 全年齢層の傷害死と年齢調整生存年数（DALYs） & 相対危険度 2.0 \\
\hline 過密状態 & 結核 & 相対危険度 1.5 \\
\hline 室内の寒さ & 冬季の過劋死亡率 & $1^{\circ} \mathrm{C}$ あたり $0.15 \%$ 死亡率増加 \\
\hline 交通騒音 & 虚血性心疾患（心筋梗塞含む） & 相対危険度 1.17/10 dB (A) \\
\hline ラドン & 肺がん & 相対危険度 $1.08 / 100 \mathrm{~Bq} / \mathrm{m}^{3}$ \\
\hline 住居内の受動喫煙 & 下気道感染症, 喘息, 心疾患, 肺がん & 相対危険度 1.2-2.0 \\
\hline 鉛 & 知的障害, 循環器疾患, 行動障害 & オッズ比 4.4 \\
\hline 室内の一酸化炭素 & 頭痛, 吐き気, 貧血, 発作, 昏睡, 意識消失, 死亡 & $\begin{array}{l}\text { 症例群致死率 3\% } \\
\text { 遅発性 / 持続性神経障害発生率 3-40\% }\end{array}$ \\
\hline ホルムアルデヒド & 子どもに扔ける呼吸器症状 & オッズ比 1.4 \\
\hline 室内での固形燃料の使用 & $\begin{array}{l}\text { 慢性閉塞性肺疾患 (COPD), 急性下気道感染症 (AIRI), } \\
\text { 伂がん }\end{array}$ & 相対危険度 1.5-3.2 \\
\hline
\end{tabular}

環境内での活発な移動手段（歩行や自転車の利用），水 の衛生，空気質などの課題を取り上げてガイドラインの 開発を進めている。

\section{おわりに}

新たな技術や素材の開発, 我々の暮らしの変化, 医療 や福祉に対する要求水準の向上，関係業界による規制へ の対応などにより，住環境は変化をとげ，住環境に求め られる要素とそのレベルも変化していく。そのためこれ らの変化に対応するためには, 継続的な調査や研究が必 要である。

利益相反：なし

\section{文献}

（1）東 賢一. 医学から見た住環境. 筏 義人, 吉田 修 (編), 住居医学 (IV). 市川 : 米田出版, 2010, 11-34.

( 2 ) Winslow CEA, et al. Basic Principles of Healthful Housing. Am J Public Health 1938;28:351-372.

（3）東 賢一. 住宅と健康. 佐藤祐造, 柴田英治（編）, テキスト健康科学改訂第 2 版. 東京 : 南江堂, 2017 , 219-230.

（4）日本救急医学会熱中症に関する委員会. 熱中症の実態 調査一日本救急医学会 Heatstroke STUDY2012 最終報 告一. 日救急医会誌 2014;25:846-862.

( 5 ) Harper GJ. Airborne micro-organisms survival test with 4 viruses. J Hyg (Lond) 1961;59:479-486.

(6) Hemmes JH, Winkler KC, Kool SM. Virus survival as a seasonal factor in influenza and poliomyelitis. Antonie van Leeuwenhoek 1962;28:221-233.

( 7 ) Lowen AC, Mubareka S, Steel J, Palese P. Influenza virus transmission is dependent on relative humidity and temperature. PLoS Pathog 2007;3:1470-1476.
( 8 ) Hanley BP, Borup B. Aerosol influenza transmission risk contours: a study of humid tropics versus winter temperate zone. Virol J 2010;7:98.

( 9 ) Jaakkola K, Saukkoriipi A, Jokelainen J, Juvonen R, Kauppila J, Vainio O, Ziegler T, Rönkkö E, Jaakkola JJ, Ikäheimo TM; KIAS-Study Group. Decline in temperature and humidity increases the occurrence of influenza in cold climate. Environ Health 2014;13:22.

(10) Ikäheimo TM, Jaakkola K, Jokelainen J, Saukkoriipi A, Roivainen M, Juvonen R, Vainio O, Jaakkola JJ. A decrease in temperature and humidity precedes human rhinovirus infections in a cold climate. Viruses 2016;8:pii:E244.

(11) WHO Europe. WHO guidelines for indoor air quality: dampness and mould. World Health Organization Regional Office for Europe, Copenhagen, 2009.

(12) WHO Europe. Night noise guidelines for Europe. World Health Organization Regional Office for Europe, Copenhagen, 2009.

（13）厚生労働省．室内空気中化学物質の指針值の見直しの 仕方等について (案). 第 17 回シックハウス（室内空 気污染）問題に関する検討会配付資料，平成 25 年 8 月 1 日.

（14）厚生労働省. 室内空気污染に係るガイドライン案につ いて. 第 21 回シックハウス（室内空気污染）問題に 関する検討会配付資料，平成 29 年 4 月 19 日。

(15) WHO Europe. Environmental burden of disease associated with inadequate housing. A method guide to the quantification of health effects of selected housing risks in the WHO European Region. Summary report. World Health Organization Regional Office for Europe, Copenhagen, 2011.

(16) WHO. International Workshop on Housing, Health and Climate Change: Developing guidance for health protection in the built environment mitigation and adaptation responses. Meeting report. Geneva, 13-15 October, 2010.

(17) WHO. WHO Housing and health guidelines. Public Health and Environment e-News, WHO Geneva, July 2013. 